\title{
PENGELOLAAN KEUANGAN DESA, APAKAH MELIBATKAN MASYARAKAT DAN TRANSPARAN?
}

\author{
Baiq Rosyida Dwi Astuti \\ Universitas Mataram \\ rosyidaunram@gmail.com \\ Wirawan Suhaedi \\ Universitas Mataram \\ wirawan.suhaedi@unram.ac.id \\ Intan Rakhmawati \\ Universitas Mataram \\ intanrakhmawati@gmail.com
}

$$
\begin{array}{ll}
\text { Diterima } & : 24 \text { April } 2020 \\
\text { Direview } & : \text { 20 Mei } 2020 \\
\text { Diterima } & : 5 \text { Juni } 2020
\end{array}
$$

\begin{abstract}
This study aims to determine the level of community participation and the level of transparency of the village government in village financial management in the districts of West Lombok and East Lombok. An assessment of the level of participation and transparency is based on an assessment from the viewpoint of the community. The research data were obtained by conducting a survey through 31 statements given to respondents. Data obtained from 13 villages, namely 8 villages in West Lombok and 5 villages in East Lombok. The number of respondents are 182 people.

The results showed that the level of village community participation and their perceptions of transparency in village financial management were high. Meanwhile, if compared between districts, the level of participation and public perception about transparency in East Lombok Regency is higher than in West Lombok Regency.

Keywords: Participation, Transparency, Village Financial Management
\end{abstract}

\begin{abstract}
Abstrak
Penelitian ini bertujuan untuk mengetahui tingkat partisipasi masyarakat dan tingkat transparansi pemerintah desa dalam pengelolaan keuangan desa di Kabupaten Lombok Barat dan Lombok Timur. Penilaian tingkat partisipasi dan
\end{abstract}


transparansi berdasarkan penilaian dari sudut pandang masyarakat. Data penelitian diperoleh dengan melakukan survey melalui 31 pernyataan yang diberikan kepada responden. Data diperoleh dari 11 desa, yaitu 6 desa di Lombok Barat dan 5 desa di Lombok Timur. Jumlah responden 162 orang.

Hasil penelitian menunjukkan bahwa tingkat partisipasi masyarakat desa dan persepsi mereka tentang transparansi pengelolaan keuangan desa dalam kategori tinggi. Sedangkan jika dibandingkan antar kabupaten, tingkat partisipasi dan persepsi masyarakat tentang transparansi di Kabupaten Lombok Timur lebih tinggi dibandingkan dengan Kabupaten Lombok Barat.

\section{Kata Kunci : Partisipasi, Transparansi, Pengelolaan Keuangan Desa}

\section{PENDAHULUAN}

Praktik pengelolaan keuangan desa dimulai semenjak pemerintah menetapkan UU No. 6/2014 tentang Desa. Semangat UU ini adalah menyelenggarakan pembangunan yang dimulai dari lingkup terkecil organisasi pemerintah yaitu desa. Salah satu tujuan yang ingin dicapai adalah peningkatan perekonomian desa yang ditujukan sebesar-besarnya untuk kemakmuran masyarakat desa. Selain itu, amanat UU ini adalah agar pembangunan desa dilakukan secara partisipatif dan mengedepankan prinsip tranparansi dalam pelaksanaan.

Klaim tentang penerapan prinsip partisipatif dalam pembangunan telah digunakan sejak empat dasawarsa. Namun dalam praktiknya, penerapan prinsip ini belum sepenuhnya memadai yang disebabkan oleh sistem dan proses penganggaran yang panjang. Sistem penganggaran daerah dimulai dari proses penyaringan aspirasi masyarakat tingkat pertama yaitu melalui Musyawarah Perencanaan dan Pembangunan Desa (Musrenbangdes). Selanjutnya daftar aspirasi hasil Musrenbangdes menjadi masukan dalam Musrenbang Kecamatan dan daftar prioritas pembangunan di kecamatan menjadi masukan pada Musrenbang Kabupaten/Kota. Hasil Musrenbang Labupaten/Kota masih diselaraskan dengan hasil Musrenbang Forum SKPD, 
Astuti, Suhaedi \& Rakhmawati: Pengelolaan Keuangan Desa...

menjadi input dalam Musrenbang Provinsi dan menghasilkan Rencana Kerja Pemerintah Daerah (RKPD). Panjanganya proses tersebut menyebabkan terjadi asimetri antara permasalahan yang dihadapi masyarakat dengan perencanaan dan anggaran pembangunan pemerintah pada tingkat yang lebih tinggi (Bastian, 2009 : 21). Aspirasi dan kebutuhan masyarakat yang telah dihimpun dalam Musrenbangdes seringkali tidak tercermin dalam RKPD. Selain proses yang panjang, budaya lama yang masih eksis sampai saat ini adalah pelaksanaan Musrenbang yang tidak sesuai dengan tujuannya. Musrenbangdes lebih menjadi acara seremonial (Toyyib dkk, 2017) daripada acara urun rembug untuk penyaluran aspirasi dan kebutuhan masyarakat. Desa yang diteliti Toyyib dkk (2017) melakukan Musrenbangdes atas instruksi kecamatan dan hanya dihadiri oleh aparat desa dan kepala dusun tanpa kehadiran semua unsur masyarakat.

Selain prinsip partisipatif, prinsip transparansi menjadi prinsip dalam pengelolaan keuangan desa. Sebagaimana amanat UU No 14/2008, bahwa entitas publik yang tugas pokoknya melakukan penyelenggaraan negara wajib menyediakan informasi publik yang benar, akurat dan tidak menyesatkan. Aparat pemerintah desa berkewajiban untuk menyediakan informasi publik terkait dengan tugas yang dilakukannya, baik untuk penyelenggaraan pemerintah maupun pelaksanaan pembangunan masyarakat. Keterbukaan pengelolaan keuangan desa dapat diterapkan sejak melakukan perencanaan sampai dengan laporan keuangan disampaikan. Implementasi prinsip transparansi dapat berupa transparansi tentang proses penyusunan anggaran, program dan alokasi dana; transparansi tentang alur pengambilan keputusan dan pelaksanaan anggaran; serta transparansi atas pertanggungjawaban penggunaan dana. Prinsip transparansi diperlukan sebagai upaya untuk mendorong partisipasi publik dalam proses pengambilan kebijakan publik (Pasal 3, UU 14/2008), demikian pula bagi masyarakat desa. Masyarakat akan memperoleh informasi dan perspektif yang lebih lengkap bila aparat desa 
menginformasikan dan mengungkapkan proses yang dilakukan sejak perencanaan sampai dengan pelaporan pengelolaan keuangan desa. Pemahaman dan perspektif yang lebih luas akan mendorong masyarakat untuk lebih aktif dalam menyampaikan aspirasi maupun turut serta mengawasi pengelolaan keuangan desa dan hasil-hasilnya.

Penelitian tentang pengelolaan keuangan desa di provinsi NTB telah banyak dilakukan, diantaranya oleh Suhaedi dkk (2016), Wirashanthi (2017), Hardiyanti (2017), Rinanto (2017), dan Wahyudi dkk (2017). Fokus penelitian adalah membandingkan kesesuaian implementasi pengelolaan keuangan desa dengan Permendagri No 113/2014 tentang Pengelolaan Keuangan desa. Hasil penelitian menunjukkan bahwa aparat desa melakukan proses perencanaan dan penganggaran dengan melibatkan masyarakat. Terdapat dokumen yang lengkap tentang kehadiran masyarakat dalam Musrenbangdes. Sedangkan prinsip transparansi dilakukan melalui penyediaan baliho besar di kantor desa tentang anggaran dan realisasi pendapatan dan belanja desa, serta penyediaan informasi di web desa. Informan penelitian-penelitian tersebut adalah aparat desa.

Penelitian tentang implementasi pengelolaan keuangan desa dari sisi persepsi masyarakat desa masih terbatas. Diantaranya penelitian yang pernah dilakukan adalah Sari dkk (2016), Isti dkk (2017) dan Toyyib (2017). Sari dkk (2016) menyimpulkan bahwa sebagian besar masyarakat menilai negatif kinerja aparatur desa. Masyarakat juga kurang paham tentang indikator kinerja yang seharusnya dimiliki dan dilakukan oleh aparat desa. Sedangkan Isti dkk (2017) meyimpulkan bahwa tingkat partisipasi masyarakat cukup tinggi dan masyarakat telah merasakan manfaat dana desa. Di sisi lain masyarakat menilai bahwa dana desa belum dapat meningkatkan kesejahteraan masyarakat. Hasil penelitian tersebut sejalan dengan Toyyib 
Astuti, Suhaedi \& Rakhmawati: Pengelolaan Keuangan Desa...

dkk (2017) dimana tokoh masyarakat tidak mengetahui bagaimana rencana kerja dan pengelolaan anggaran desa.

Penelitian untuk mengetahui persepsi masyarakat tentang pengelolaan keuangan desa penting untuk dilakukan berdasarkan pertimbangan berikut. Pertama, diperlukan data yang berimbang tentang sejauh bagaimana pengelolaan keuangan desa telah dijalankan. Data yang diperoleh dari masyarakat desa sebagai stakeholder utama akan mengkonfirmasi hasil penelitian sebelumnya. Kedua, pengelolaan keuangan publik yang baik membutuhkan keterlibatan masyarakat, baik sebagai pengawas maupun pemberi aspirasi. Oleh karena itu perlu dibangun kesadaran masyarakat desa tentang pentingnya akuntabilitas pengelolaan keuangan desa. Penelitian ini adalah penelitian dasar untuk membangun penelitian-penelitian berikutnya tentang pengembangan kesadaran masyarakat tentang akuntabilitas pengelolaan keuangan desa. Berdasarkan penelitian Wibisono dkk (2017), partisipasi masyarakat berperan unutuk memperkuat pengelolaan keuangan desa.

Penelitian ini bertujuan untuk mengetahui pendapat masyarakat tentang pengelolaan keuangan desa yang dilakukan oleh pemerintah desa di Pulau Lombok, yaitu tentang keterlibatan masyarakat serta transparansi pengelolaan. Penelitian sejenis belum pernah dilakukan di NTB.

\section{TELAAH LITERATUR}

Suhaedi dkk (2016) meneliti tentang kesesuaian antara proses perencanaan dan pelaksanaan dengan Permendagri 113/2014. Hasil penelitian menunjukkan bahwa masyarakat desa terlibat dalam proses perencanaan namun terkendala dengan lamanya menunggu persetujuan dari atas usulan yang dikirim ke Pemerintah Kabupaten dan mengalami masalah ketika melakukan penyusunan anggaran untuk pembangunan infrastruktur. 
Wirashanthi (2017) meneliti tentang kesesuaian penatausahaan dan pelaporan keuangan desa di kabupaten Lombok Barat dengan Permendagri 113/2014. Ia menyimpulkan bahwa penatausahaan keuangan desa sudah dilakukan sesuai dengan peraturan yang berlaku namun tidak demikian dengan pelaporan keuangannya. Sebagian besar desa sampel penelitian tidak membuat laporan realisasi pelaksanaan APBDes serta isi dan struktur laporan tidak sesuai dengan peraturan.

Hardiyanti (2017) meneliti tentang pengelolaan keuangan Desa Gelangsar yang memperoleh predikat Desa Pelopor Good Governance di Kabupaten Lombok Barat. Hasil penelitian menunjukkan bahwa pengelolaan keuangan desa dilakukan dengan cukup terencana dengan melibatkan pendapat ahli dari luar desa dalam proses perencanaan. Desa juga memiliki web sendiri yang menginformasikan tentang program, anggaran dan hasil dari kegiatam yang dilakukan oleh desa. Kepala Desa menjadi motor penggerak dalam melaksanakan program desa.

Rinanto (2017) meneliti tentang akuntabilitas pengelolaan keuangan desa di Kecamatan Gunungsari dan Narmada Kabupaten Lombok Barat. Peneliti tidak dapat mengakses dokumen tentang kehadiran peserta Musrenbang pada sebagian besar desa. Pihak desa beralasan bahwa dokumen tersebut sedang dalam pemeriksaan pihak inspektorat. Selain itu peneliti juga menyimpulkan bahwa desa tidak memiliki sistem dokumentasi yang baik. Pada tahap pertanggungjawaban, hanya sebagian kecil desa yang tepat waktu menyampaikan Laporan Pertanggungjawaban Realisasi Pelaksanaan APBDesa.

Sari dkk (2016) mengkaji tentang persepsi masyarakat tentang kinerja aparatur desa di. Hasil penelitian menunjukkan bahwa (a) pemahaman masyarakat tentang indikator kinerja organisasi publik rendah dan (b) tanggapan masyarakat negatif atas kinerja aparatur desa. Isti dkk (2017) meneliti tentang persepsi dan partsipasi masyarakat dalam pemanfaatan dana 
Astuti, Suhaedi \& Rakhmawati: Pengelolaan Keuangan Desa...

desa. Hasil penelitiannya menunjukkan bahwa persepsi dan partisipasi masyarakat cukup tinggi. Toyyib dkk (2017) meneliti tentang pelaksanaan Musrenbangdes. Penelitiannya menyimpulkan bahwa pelaksanaan Musrendangdes hanya menjadi formalitas untuk menggugurkan kewajiban. Penyelenggaran Musrenbangdes adalah pihak kecamatan, bukan pihak pemerintah desa dan pesertanya hanya aparat desa. Dokumen perencanaanpun disusun oleh pihak kecamatan. Tokoh masyarakat yang diwawancara juga tidak mengetahui bagaimana dan kemana keuangan desa digunakan. Hasil penelitian ini menunjukkan tingkat transparansi dan partisipasi yang buruk.

Wibisono dkk (2017) menyimpulkan bahwa lemahnya pengelolaan dana desa atau kecendrungan penyalahgunaan dana desa disebabkan oleh beberapa hal, yaitu tidak berfungsinya peran pendamping desa; lemahnya pembinaan dan pengawasan dari pihak kecamatan, Tim Pengawalan Pengamanan Pemerintahan dan Pembangunan, pengawasan BPD dan partisipasi masyarakat; tingginya biaya non budgetair dan SDM pengelola keuangan desa yang tidak cakap.

\section{METODE PENELITIAN}

\section{Jenis Penelitian, Instrumen Penelitian dan Metode Pengumpulan Data}

Metode yang digunakan dalam penelitian ini adalah metode penelitian deskriptif-kualitatif. Penelitian deskriptif merupakan penelitian tentang faktafakta saat ini dari suatu populasi dan bertujuan untuk menjawab pertanyaan yang berkaitan dengan kondisi terkini (current status) dari subyek yang diteliti (Indriantoro dan Supomo, 2002 : 26). Penelitian ini berusaha menggali informasi tentang pendapat masyarakat atas keterlibatan mereka dalam pengelolaan keuangan desa, serta pendapat mereka tentang tingkat tranparansi yang dilakukan oleh pemerintah desa. 
Instrumen penelitian menggunakan lembar survey yang didalamnya memuat pernyataan-pernyataan tentang obyek penelitian. Tiap pernyataan menyediakan pilihan jawaban skala 1 sampai dengan 10. Nilai 1 menunjukkan tingkat persetujuan yang paling rendah dan nilai 10 menunjukkan tingkat persetujuan yang paling tinggi. Peneliti menggunakan Skala Likert 1 sampai dengan 10 karena rata-rata masyarakat desa memiliki tingkat pendidikan yang relatif rendah, sehingga akan lebih mudah bagi mereka untuk membayangkan dan memahami penilaian dengan menggunakan nilai 1 sampai dengan 10 . Terdapat 31 buah pernyataan dalam lembar survey, terdiri dari 15 pernyataan untuk partisipasi masyarakat dan 16 pernyataan untuk transparansi pemerintah desa. Berikut rincian obyek penelitian, indikator dan jumlah pernyataan untuk masing-masing indikator.

Tabel 1. Obyek, Indikator dan Jumlah Pernyataan

\begin{tabular}{|c|c|c|c|}
\hline Obyek & Indikator & $\begin{array}{c}\text { Jumlah } \\
\text { Pernyataan }\end{array}$ & Referensi \\
\hline \multirow{3}{*}{ Partisipasi } & $\begin{array}{l}\text { Partisipasi } \text { dalam } \\
\text { pengambilan keputusan dan } \\
\text { evaluasi }\end{array}$ & 4 & \multirow{3}{*}{$\begin{array}{l}\text { Ndraha } \\
(1990) \\
\text { dalam } \\
\text { Laksana } \\
(2013)\end{array}$} \\
\hline & $\begin{array}{ll}\text { Partisipasi } & \text { dalam } \\
\text { pelaksanaan } & \\
\end{array}$ & 4 & \\
\hline & $\begin{array}{l}\text { Partisipasi } \text { dalam } \\
\text { pengambilan manfaat }\end{array}$ & 7 & \\
\hline \multirow{3}{*}{ Transparansi } & $\begin{array}{lr}\text { Transparansi } & \text { dalam } \\
\text { perencanaan } & \text { dan } \\
\text { penganggaran } & \\
\end{array}$ & 10 & \multirow{3}{*}{$\begin{array}{l}\text { Kepmenpan } \\
\text { 26/2004 }\end{array}$} \\
\hline & $\begin{array}{l}\text { Transparansi } \\
\text { pelaksanaan }\end{array}$ & 3 & \\
\hline & $\begin{array}{l}\text { Transparansi } \\
\text { pelaporan }\end{array}$ & 3 & \\
\hline
\end{tabular}

Pengumpulan data dilakukan pada bulan Agustus s.d Oktober 2018. Responden penelitian dipilih dengan teknik random sampling yang berasal dari 12 desa di Kabupaten Lombok Barat dan Lombok Timur. Teknik ini digunakan 
Astuti, Suhaedi \& Rakhmawati: Pengelolaan Keuangan Desa...

karena semua masyarakat (populasi) memiliki kesempatan yang sama untuk menjadi responden penelitian. Tabel 2 menunjukkan rincian responden.

Tabel 2. Nama Desa dan Jumlah Responden Tiap Desa

\begin{tabular}{lll}
\hline \multirow{2}{*}{ Kabupaten } & \multicolumn{1}{c}{ Desa } & $\begin{array}{c}\text { Jumlah } \\
\text { responden }\end{array}$ \\
\hline \multirow{4}{*}{ Lombok Barat } & Batu Kumbung & 11 \\
\cline { 2 - 3 } & Kuripan & 10 \\
\cline { 2 - 3 } & Bajur & 15 \\
\cline { 2 - 3 } & Rumak & 15 \\
\cline { 2 - 3 } & Bagik Nunggal & 20 \\
\cline { 2 - 3 } Karang Bongkot & 17 \\
\hline \multirow{4}{*}{ Lombok Timur } & Teros & 14 \\
\cline { 2 - 3 } & Labuhan Haji & 15 \\
\cline { 2 - 3 } & Montong Betok & 16 \\
\cline { 2 - 3 } & Masbagik Utara Baru & 162 \\
\cline { 2 - 3 } & Pengadangan & 16 \\
\hline
\end{tabular}

\section{Teknik Analisa Data}

Penelitian ini menggunakan lima kategori untuk menilai tingkat partisipasi dan transparansi yaitu "Sangat Rendah", "Rendah", "Sedang", "Tinggi" dan "Sangat Tinggi". Interval antar kategori dihitung dengan cara membagi skor tertinggi ideal dengan jumlah kategori.

$$
\text { Interval Antar Kategori }=\frac{10 \times \text { Jumlah Pernyataan }}{5}
$$

Penilaian dilakukan untuk tiap indikator maupun obyek penelitian. Skor indikator untuk masing-masing responden dihitung dengan menjumlahkan seluruh nilai yang diberikan responden untuk tiap pernyataan. Skor indikator masing-masing responden kemudian dimasukkan ke dalam salah satu dari lima kategori yang sesuai. Selanjutnya akan diperoleh persentase jumlah responden untuk masing-masing kategori. Perhitungan dan cara yang sama juga dilakukan untuk menghitung skor obyek penelitian. Hasil perhitungan 
menjadi dasar bagi peneliti untuk menganalisa kecendrungan tingkat partisipasi dan transparansi pengelolaan keuangan desa.

\section{HASIL PENELITIAN DAN PEMBAHASAN}

\section{Kategorisasi, Demografi Responden dan Statistik Deskriptif}

Berdasarkan nilai total minimum dan maksimum yang diharapkan, maka kategori penilaian untuk tingkat partisipasi dan transparansi adalah :

Tabel 3. Kategori Penilaian dan Interval Nilai Kategori

\begin{tabular}{lcc}
\hline \multicolumn{1}{c}{ Kategori } & Partisipasi & Partisipasi \\
\hline Sangat rendah & $0-30$ & $0-32$ \\
\hline Rendah & $31-60$ & $33-64$ \\
\hline Sedang & $61-90$ & $65-96$ \\
\hline Tinggi & $91-120$ & $97-128$ \\
\hline Sangat Tinggi & $121-150$ & $129-160$ \\
\hline
\end{tabular}

Sedangkan demografi responden ditunjukkan sebagai berikut :

Tabel 4. Demografi Responden

\begin{tabular}{clcc}
\hline \multirow{2}{*}{ No } & \multirow{2}{*}{ Karakteristik Responden } & \multicolumn{2}{c}{ Jumlah } \\
\cline { 2 - 4 } Jenis Kelamin & Orang & $\%$ \\
\hline 1 & Laki-laki & 79 & 48,8 \\
\hline 2 & Perempuan & 83 & 51,2 \\
\hline Total & 162 & 100,0 \\
\hline Profesi/Pekerjaan & & \\
\hline 1 & Wiraswasta & 46 & 28,4 \\
\hline 2 & Staf Desa & 2 & 1,2 \\
\hline 3 & Pelajar/mahasiswa & 16 & 9,9 \\
\hline 4 & Petani/Pekebun & 17 & 10,5 \\
\hline 5 & Ibu Rumah tangga & 43 & 26,5 \\
\hline 6 & PNS/Pensiunan/Guru/karyawan & 10 & 6,2 \\
\hline 7 & Pekerja Lepas & 17 & 10,5 \\
\hline 8 & Lain-lain & 11 & 6,8 \\
\hline Total & 162 & 100,0 \\
\hline Tingkat Pendidikan & & \\
\hline 1 & SD & 35 & 21,6 \\
\hline
\end{tabular}


Astuti, Suhaedi \& Rakhmawati: Pengelolaan Keuangan Desa...

\begin{tabular}{clcc}
\hline 2 & SMP & 27 & 16,7 \\
\hline 3 & SMA & 83 & 51,2 \\
\hline 4 & D3 & 3 & 1,9 \\
\hline 5 & S1 & 14 & 8,6 \\
\hline Total & 162 & 100,0 \\
\hline
\end{tabular}

Responden penelitian ini sebanyak $51,2 \%$ berjenis kelamin laki-laki dan sisanya $48,4 \%$ perempuan. Berdasarkan profesi/pekerjaan, mayoritas responden berprofesi sebagai wiraswasta (28,4\%) dan IRT (26,5\%). Sebanyak 17 orang responden Pekerja lepas terdiri dari buruh tani, buruh bangunan, montir dan kader posyandu. Sedangkan responden dengan profesi lainnya adalah responden yang tidak mencantumkan pekerjaannya dan pengangguran. Sedangkan berdasarkan tingkat pendidikan, mayoritas pendidikan terakhir adalah SMA $(51,2 \%)$ dan SD $(21,6 \%)$. Mayoritas responden berpendidikan SMA sebagaimana karakteristik tingkat pendidikan yang ditempuh oleh sebagian besar masyarakat desa.

Deskripsi data berdasarkan hasil yang diperoleh ditunjukkan dalam tabel berikut :

Tabel 5. Deskripsi Data Hasil Survey

\begin{tabular}{lcc}
\hline \multicolumn{1}{c}{ Keterangan } & Partisipasi & Transparansi \\
\hline Rata-rata & 98.05 & 97.31 \\
\hline Nilai maksimum & 150 & 160 \\
\hline Nilai minimum & 28 & 20 \\
\hline Modus & 116 & 92 \\
\hline Median & 97 & 95,5 \\
\hline
\end{tabular}

Berdasarkan nilai rata-rata, modus dan median, menunjukkan bahwa sebagian besar data memusat di sekitar nilai sekitar nilai 116 untuk partisipasi dan sekitar nilai 92 untuk transparansi. Sedangkan rata-rata partisipasi adalah 98,05 dan transparansi 97,31. Ketika dimasukkan dalam kategri yang sudah ditentukan di atas, maka nilai rata-rata tingkat pasrtisipasi dan transparansi dalam kategori tinggi. 


\section{Tingkat Partisipasi dan Persepsi Tentang Transparansi}

Penilaian responden tentang tingkat partisipasi dan transparansi ditunjukkan dalam tabel berikut :

Tabel 6. Penilaian Tingkat Partisipasi dan Transparansi

\begin{tabular}{lcccc}
\hline \multirow{2}{*}{ Kriteria } & \multicolumn{2}{c}{ Partisipasi } & \multicolumn{2}{c}{ Transparansi } \\
\cline { 2 - 5 } & Orang & $\%$ & Orang & $\%$ \\
\hline Sangat rendah & 2 & 1,2 & 1 & 0,06 \\
\hline Rendah & 29 & 17,9 & 32 & 19,8 \\
\hline Cukup & 44 & 27,2 & 48 & 29,6 \\
\hline Tinggi & 45 & 27,8 & 59 & 36,4 \\
\hline Sangat tinggi & 42 & 25,9 & 22 & 13,6 \\
\hline
\end{tabular}

Mayoritas responden menilai tingkat partisipasi mereka tinggi dan cukup (27,8\% dan $27,2 \%$ ) dalam pengelolaan keuangan desa. Lebih dari seperempat responden juga menilai partisipasi mereka sangat tinggi $(25,9)$. Sebagian besar responden menilai bahwa partisipasi mereka tinggi dalam pengambilan keputusan, evaluasi, pelaksanaan dan pengambilan manfaat pengelolaan keuangan desa. Sedangkan sebagian besar responden $(36,4 \%)$ menilai transparansi aparat desa dalam pengelolaan keuangan desa tinggi, namun hanya $13,6 \%$ yang menilai sangat tinggi.

\section{Tingkat Partisipasi dan Persepsi Tentang Transparansi Berdasarkan Demografi Responden}

\section{A. Jenis Kelamin}

Tabel 7. Tingkat Partisipasi dan Transparansi

Berdasarkan Jenis Kelamin

\begin{tabular}{lll}
\hline Keterangan & Partisipasi & Transparansi \\
\hline Laki-laki & $52,01 \%$ & $51,24 \%$ \\
\hline Perempuan & $47,99 \%$ & $48,76 \%$ \\
\hline
\end{tabular}


Astuti, Suhaedi \& Rakhmawati: Pengelolaan Keuangan Desa...

Bila dilihat secara keseluruhan, tingkat partisipasi laki-laki lebih tinggi dari perempuan. Begitupun dengan penilaian tentang transparansi pengelolaan keuangan desa. Penilaian laki-laki tentang tingkat transparansi pengelolaan keuangan desa lebih tinggi dari penilaian perempuan. Sedangkan apabila dilihat berdasarkan kriteria penilaian, penilaian laki-laki dan perempuan tentang partisipasi dan transparansi pengelolaan keuangan desa adalah sebagai berikut :

Tabel 8. Penilaian Tingkat Partisipasi dan Transparansi

Berdasarkan jenis Kelamin

\begin{tabular}{lcccc}
\hline \multirow{2}{*}{ Kriteria } & \multicolumn{2}{c}{ Partisipasi } & \multicolumn{2}{c}{ Transparansi } \\
\cline { 2 - 5 } & $\mathrm{L}$ & $\mathrm{P}$ & $\mathrm{L}$ & $\mathrm{P}$ \\
\hline Sangat rendah & $0,5 \%$ & $0,5 \%$ & $0 \%$ & $0,5 \%$ \\
\hline Rendah & $8,8 \%$ & $7,1 \%$ & $9,3 \%$ & $8,2 \%$ \\
\hline Cukup & $11,5 \%$ & $13,2 \%$ & $13,2 \%$ & $13,2 \%$ \\
\hline Tinggi & $11,0 \%$ & $16,5 \%$ & $16,5 \%$ & $20,3 \%$ \\
\hline Sangat tinggi & $19,8 \%$ & $11,0 \%$ & $12,6 \%$ & $6,0 \%$ \\
\hline
\end{tabular}

Catatan : $\mathrm{L}=$ Laki-Laki dan $\mathrm{P}=$ Perempuan

Berdasarkan data pada tabel 8, partisipasi dan persepsi tentang transparansi pengelolaan keuangan desa antara laki-laki dan perempuan tidak menunjukkan perbedaan yang signifikan. Tingkat partisipasi menyebar secara merata pada kategori cukup, tinggi dan sangat tinggi. Pola yang mirip terjadi juga dengan persepsi mereka tentang transparansi pengelolaan keuangan desa.

\section{B. Tingkat Pendidikan}

Tabel 9. Penilaian Partisipasi dan Transparansi

Berdasarkan Tingkat Pendidikan

\begin{tabular}{ccc}
\hline Keterangan & Partisipasi & Transparansi \\
\hline SD & 95,59 & 93,92 \\
\hline SMP & 97,74 & 95,13 \\
\hline SMA & 96,17 & 97,90 \\
\hline D3 & 87,75 & 95,25 \\
\hline S1 & 116,29 & 105,88 \\
\hline
\end{tabular}


Partisipasi responden dengan tingkat pendidikan S1 jauh lebih tinggi dari tingkat pendidikan di bawahnya. Begitu pula dengan penilaian transparansi pengelolaan keuangan desa, responden dengan tingkat pendidikan S1 menilai pengelolaan keuangan desa lebih transparan dibandingkan dengan penilaian responden dengan tingkat pendidikan di bawah $\mathrm{S} 1$. Namun bila dilihat secara keseluruhan, tingkat partisipasi responden memiliki nilai yang homogen walaupun berasal dari tingkat pendidikan yang berbeda. Begitu pula dengan persepsi mereka tentang pengelolaan keuangan desa, penilaian responden homogen.

\section{Profesi/Pekerjaan}

Tabel 10. Penilaian Partisipasi dan Transparansi Berdasarkan Profesi/Pekerjaan

\begin{tabular}{lcc}
\hline Keterangan & Partisipasi & Transparansi \\
\hline Wiraswasta & 90,00 & 88,21 \\
\hline Aparat Desa & 134,10 & 128,50 \\
\hline Pelajar/Mahasiswa & 91,71 & 88,47 \\
\hline Petani/pekebun & 126,95 & 117,14 \\
\hline IRT & 84,34 & 86,39 \\
\hline PNS/Pensiunan/Guru/Karyawan & 106,25 & 101,00 \\
\hline Pekerja Lepas & 95,35 & 101,24 \\
\hline Lain-lain & 103,54 & 114,85 \\
\hline
\end{tabular}

Penilaian responden yang berprofesi sebagai aparat desa diabaikan dalam kategori ini karena dapat bermakna bias. Responden yang berprofesi sebagai Petani/Pekebun, PNS/Pensiunan/Guru/Karyawan, dan pekerjaan lain-lain memiliki partisipasi yang lebih tinggi dibandingkan profesi/pekerjaan yang lain. Demikian pula penilaian mereka tentang transparansi pengelolaan keuangan desa lebih tinggi dari profesi lainnya. Profesi/pekerjaan yang berpartisipasi lebih rendah dan menilai transparansi rendah adalah dari kalangan wiraswasta, pelajar/mahasiswa, pekerja lepas dan IRT. 
Astuti, Suhaedi \& Rakhmawati: Pengelolaan Keuangan Desa...

\section{Desa}

Tabel 11. Penilaian Partisipasi dan Transparansi Berdasarkan Desa

\begin{tabular}{clcc}
\hline Kabupaten & \multicolumn{1}{c}{ Desa } & Partisipasi & Transparansi \\
\hline \multirow{3}{*}{$\begin{array}{c}\text { Lombok } \\
\text { Barat }\end{array}$} & Batu kumbung & 44,18 & 59,27 \\
\cline { 2 - 4 } & Kuripan & 114,30 & 103,80 \\
\cline { 2 - 4 } & Bajur & 90,60 & 94,67 \\
\cline { 2 - 4 } & Rumak & 82,53 & 89,73 \\
\cline { 2 - 4 } & Bagik nunggal & 75,05 & 70,04 \\
\cline { 2 - 4 } & Karang bongkot & 67,29 & 68,00 \\
\hline \multirow{3}{*}{ Lombok } & Teros & 114,57 & 113,86 \\
\cline { 2 - 4 } & Labuhan Haji & 105,13 & 95,80 \\
\cline { 2 - 4 } & Montong betok & 126,56 & 112,88 \\
\cline { 2 - 4 } & Masbagik Utara & 106,86 & 104,71 \\
\cline { 2 - 4 } & Pengadangan & 113,60 & 120,20 \\
& & & \\
& &
\end{tabular}

Responden di Desa Montong Betok Kab Lombok Timur memiliki tingkat partisipasi yang paling tinggi dibandingkan dengan desa-desa lainnya. Desa dengan tingkat partisipasi tertinggi kedua, ketiga dan keempat adalah Desa Teros Kab Lombok Timur, Desa Kuripan Kab Lombok Barat dan Desa Pengadagangan Kab Lombok Timur. Responden di Desa Batu Kumbung Kab Lombok Barat memiliki partisipasi yang paling rendah di antara semua desa. Sedangkan penilaian tentang transparansi pengelolaan keuangan desa tertinggi di Desa Pengadangan Kab Lombok Timur. Penilaian tingkat transparansi tertinggi kedua, ketiga dan keempat adalah Desa Teros, Desa Montong Betok dan Desa Masbagik Kab Lombok Timur. Penilaian transparansi yang terendah adalah di Desa Batu Kumbung. 


\section{E. Kabupaten}

Tabel 12. Penilaian Partisipasi dan Transparansi

Berdasarkan Kabupaten

\begin{tabular}{lcc}
\hline Keterangan & Lombok Barat & Lombok Timur \\
\hline Partisipasi & 91,68 & 113,34 \\
\hline Transparansi & 92,22 & 109,49 \\
\hline
\end{tabular}

Tabel 12 menunjukkan tingkat partisipasi dan transparansi di Kabupaten Lombok Timur lebih tinggi dari tingkat pratisipasi dan transparansi di Kabupaten Lombok Barat. Hal tersebut dipengaruhi oleh tingkat partisipasi dan transparansi pengelolaan keuangan desa di desa-desa yang terletak di Kabupaten Lombok Timur lebih tinggi dari desa-desa di Kabupaten Lombok Barat.

\section{SIMPULAN}

Tingkat partisipasi masyarakat dalam hal pengambilan, evaluasi, pelaksanaan dan manfaat dari pengelolaan keuangan desa dalam kategori tinggi. Sedangkan persepsi masyarakat tentang transparansi pengelolaan keuangan desa dalam hal perencanaan, pelaksanaan dan pelaporan dalam kategori tinggi. Berdasarkan jenis kelamin, tingkat partisipasi dan persepsi laki-laki tentang transparansi lebih tinggi dibandingkan perempuan. Masyarakat dengan latar belakang pendidikan S1 lebih berpartisipasi dibandingkan masyarakat dengan latar belakang pendidikan di bawah S1. Demikan pula dengan persepsi mereka tentang transparansi pengelolaan keuangan desa lebih tinggi dibandingkan latar belakang pendidikan lainnya.

Berdasarkan profesi/pekerjaan, keterlibatan petani/pekebun lebih tinggi dibandingkan profesi/pekerjaan lainnya. Walaupun memang data menunjukkan bahwa keterlibatan yang dinilai oleh staf/aparatur desa merupakan yang tertinggi namun memungkinkan terjadinya bias karena 
Astuti, Suhaedi \& Rakhmawati: Pengelolaan Keuangan Desa...

menilai kinerja sendiri sehingga data ini diabaikan. Desa Kuripan merupakan desa dengan tingkat partisipasi masyarakat yang tertinggi dibandingkan desadesa lainnya di Kabupaten Lombok Barat. Begitu pula persepsi tentang transparansi paling tinggi di Desa Kuripan. Partisipasi masyarakat desa dan persepsi mereka tentang transparansi lebih tinggi di Kabupaten Lombok Timur dibandingkan Kabupaten Lombok Barat.

Implikasi penelitian ini adalah terkait penguatan partisipasi masyarakat desa. Lebih dari setengah jumlah responden penelitian ini adalah mereka yang mengenyam pendidikan terakhir paling tinggi di tingkat SMA, namun tingkat partisipasi mereka lebih rendah dibandingkan partisipasi masyarakat yang berlatar belakang pendidikan S1 dan D3. Mengingat bahwa mayoritas masyarakat desa di Indonesia adalah mereka yang berpendidikan SMA ke bawah, maka mereka memerlukan pendampingan dan penguatan tentang arti pentingnya partisipasi dalam proses pengelolaan keuangan desa.

\section{DAFTAR PUSTAKA}

Aloys, I. D., Budiarti, L., Haryadi. (2017). Identifikasi Faktor Penyebab Keterlambatan Penetapan Anggaran Pendapatan dan Belanja Desa (APB

Desa) di Kabupaten Banjarnegara Tahun Anggaran 2015 (Paska UU No 6 Tahun 2014 Tentang Desa). Simposium Nasional Akuntansi XX. Jember: Ikatan Akuntan Indonesia

Bastian, I. (2009). Sistem perencanaan dan penganggaran Pemerintah Daerah di Indonesia. Jakarta: Penerbit Salemba Empat.

Hardiyanti, T.R. (2017). Best Practice Pengelolaan keuangan Desa (Studi Pada

Desa Gelangsar Kecamatan Gunung Sari Kabupaten Lombok Barat). Mataram: Fakultas Ekonomi dan Bisnis Universitas Mataram.

Indriantoro, N., Supomo, B. (2002). Metode Penelitian Bisnis Untuk Akuntansi dan Manajemen. Yogyakarta: BPFE UGM. 
Isti, D. N., Komar, O., Heryanto, N. (2017). Persepsi dan Partisipasi Masyarakat terhadap Pemanfaatan Dana Desa Untuk Pemberdayaan Masyarakat. Jurnal Pendidikan Luar Sekolah 1 (2017).

Keputusan Menteri Pendayagunaan Aparatur Negara dan Reformasi Birokrasi Nomor 26 Tahun 2004 Tentang Petunjuk Teknis Transparansi dan Akuntabilitas Dalam Penyelenggaraan Pelayanan Publik.

Laksana, N. S. (2013) Bentuk-Bentuk Partisipasi Masyarakat dalam Program

Desa Siaga di Desa Bandung Kecamatan Playen Kabupaten Gunung Kidul Provinsi daerah Istimewa Yogyakarta, Kebijakan dan Manajemen Publik 1 (2013).

Rinanto, E. (2017). Analisis Akuntabilitas Pengelolaan Keuangan Desa (Studi pada Desa di kecamatan Gunungsari dan kecamatan Narmada). Mataram: Fakultas Ekonomi dan Bisnis Universitas Mataram.

Sari, D. L., Hasyim, A., Nurmalisa, Y., (2017). Persepsi Masyarakat terhadap Kinerja Aparatur Desa dalam Meningkatkan Pelayanan Publik. Lampung: FKIP Universitas Lampung

Suhaedi, W., Astuti, B.R.D., Rakhmawati, Intan. (2015). Pengelolaan Keuangan Desa. Aksioma 14 (2015).

Suhaedi, W., Astuti, B.R.D., Rakhmawati, Intan. (2016). Evaluasi Pengelolaan Keuangan Desa. Aksioma 16 (2016)

Toyyib, M., Haryadi, B., Asy'ari, M. A. (2017). Perayaan Musrenbangdes Sebagai Ajang Ceremonial Tahunan. Simposium Nasional Akuntansi XX. Jember: Ikatan Akuntan Indonesia.

Undang Undang Nomor 14 Tahun 2008 Tentang keterbukaan Informasi Publik Undang-Undang Nomor 4 Tahun 2014 Tentang Desa

Wahyudi, A., Pancawati, R. S., Nurabiah. (2017). Akuntabilitas Pengelolaan Keuangan Desa di Kecamatan Unter Iwes Kabupaten Sumbawa. Simposium Nasional Akuntansi XX. Jember: Ikatan Akuntan Indonesia. 
Astuti, Suhaedi \& Rakhmawati: Pengelolaan Keuangan Desa...

Wibisono, Nurharibu, Purnomo, H. (2017). Mengungkap Fenomena Pengawasan Publik Terhadap Dana Desa di Kabupaten Madiun. Jurnal Akuntansi dan sistem Informasi 2 (2017)

Wirashanthi, K. D. (2017). Evaluasi Penatausahaan dan pelaporan Keuangan Desa di Kabupaten Lombok Barat. Mataram: Fakultas Ekonomi dan Bisnis Universitas Mataram. 